\title{
TINGKAT KESUKAAN KONSUMEN DAN KUALITAS ORGANOLEPTIK PRODUK OLAHAN IKAN
}

\section{LEVEL OF CONSUMER PREFERENCES AND ORGANOLEPTIC QUALITY OF PROCESSED FISH PRODUCTS}

\author{
Nursinah Amir ${ }^{1)}$, Metusalach ${ }^{1)}$ dan Fahrul ${ }^{1)}$ \\ ${ }^{1}$ Program Studi Pemanfaatan Sumberdaya Perikanan, Fakultas Ilmu Kelautan dan Perikanan, \\ Universitas Hasanuddin
}

Diterima: 23 Februari 2018 ; Disetujui: 22 Maret 2018

\begin{abstract}
ABSTRAK
Produk olahan ikan merupakan bentuk diversifikasi produk yang menggunakan ikan sebagai bahan dasar. Penelitian ini bertujuan untuk mengetahui tingkat kesukaan konsumen dan kualitas organoleptik produk olahan ikan. Sampel produk olahan ikan meliputi bakso, abon, nugget dan otakotak. Sampel diambil dari kelompok pengolah hasil perikanan Buyang Sejahtera dan Barokah di Kelurahan Kampung Buyang Kecamatan Mariso Kota Makassar. Tingkat kesukaan dan kualitas organoleptik ditentukan dengan menggunakan kusioner dan panelis. Hasil menunjukkan bahwa ratarata panelis mengatakan sangat suka terhadap produk abon dan nugget kelompok pengolah Buyang sejahtera, sangat suka terhadap produk otak-otak Kelompok Barokah, suka terhadap produk otakotak kelompok Buyang Sejahtera serta suka terhadap produk nugget dan bakso Kelompok Barokah.
\end{abstract}

Kata Kunci: organoleptik, bakso, nugget, abon, otak-otak

\begin{abstract}
Processed fish products are a diversified form of products that use fish as the basic ingredients. This study aims to determine the level of consumer preference and organoleptic quality of processed fish products. Samples of processed fish products include meatballs, abon, nuggets and brains. Samples were taken from the group of processing fishery products Buyang Sejahtera and Barokah in Kampung Buyang Village, Mariso Sub-District, Makassar City. The level of preference and organoleptic quality is determined by using the kusioner and panelist. The results show that the average panelist says that very like abon and nugget was production of the Buyang Sejahtera processing group, very like otakotak was production of the Barokah group, like otak-otak was production of the Buyang Sejahtera group and like the nuggets and fishballs of the Barokah Group.
\end{abstract}

Keywords: organoleptic, fishballs, nugget, abon, otak-otak

Contact person : Nursinah Amir

Email: ina thp@yahoo.co.id 


\section{PENDAHULUAN}

Ikan adalah salah satu bahan makanan yang digemari dan dikonsumsi oleh masyarakat. Secara umum ikan lebih cepat mengalami pembusukan apabila dibandingkan dengan bahan makanan lain. Berdasarkan pada kenyataan ini maka dibutuhkan teknologi pengawetan ikan ataupun olahan ikan sehingga dapat memperpanjang umur simpannya (Kusumayanti dkk., 2011).

Kota Makassar merupakan pintu gerbang Kawasan Timur Indonesia, dan menjadi salah satu pintu gerbang ekspor hasil perdagangan perikanan secara umum. Pemerintah Kota Makassar terus berupaya meningkatkan kesejahteraan masyarakatnya melalui potensi kelautan yang dimilikinya, apalagi Makassar mempunyai banyak pulau-pulau kecil serta hamparan laut. Pada tahun 2014, produksi perikanan di Kota Makassar mencapai \pm 338 Ribu Ton (Dinas Kelautan dan Perikanan Propinsi Sulawesi Selatan, 2015). Produksi perikanan ini mendukung tingginya angka konsumsi ikan di Sulawesi Selatan yaitu \pm 44 kilogram (kg)/kapita pertahun atau lebih tinggi dari rata-rata angka konsumsi ikan nasional yang hanya 23 - $24 \mathrm{~kg}$. Jenis ikan yang dikonsumsi umumnya ikan laut dengan cara penyajian sebatas dibakar, digoreng atau dimasak (Ancasindo, 2012).

Abon, bakso, nugget dan otak-otak berbahan dasar ikan, merupakan produk diversifikasi yang banyak digemari masyarakat khususnya di Kota Makassar. Beberapa kelompok pengolah hasil perikanan mayoritas mengolah produk tersebut. Abon merupakan jenis makanan olahan ikan yang diberi bumbu, diolah dengan cara perebusan/pengukusan dan penggorengan, sering dijadikan sebagai pelengkap makan roti ataupun sebagai lauk-pauk. Nugget ikan merupakan salah satu produk olahan yang memanfaatkan daging ikan dengan penambahan bumbu, bahan pengisi, dan bahan pengikat, sering digunakan sebagai cemilan maupun sebagai lauk pauk. Bakso merupakan kuliner yang digemari semua kalangan dan hampir bisa didapatkan dimanamana. Otak-otak bahkan menjadi menu pembuka di beberapa restoran dan menjadi salah satu oleh-oleh khas dari Kota Makassar.

Aroma, rasa, tekstur dan warna merupakan parameter organoleptik yang digunakan untuk mengetahui tingkat kesukaan atau penerimaan konsumen. Konsumen akan menyatakan sangat suka, suka, agak suka atau pun tidak suka terhadap produk terutama produk perikanan dengan melihat parameter tersebut. Suradi (2009) menambahkan bahwa rasa, bau dan kekenyalan merupakan faktor-foktor yang perlu mendapat perhatian dalam pembuatan bakso. Konsumen pada umumnya menyukai bakso yang kompak, elastis, kenyal tapi tidak keras dan tidak lembek.

Berdasarkan uraian di atas, peneliti melakukan penelitian untuk mengetahui tingkat kesukaan konsumen dan kualitas organoleptik terhadap produk olahan ikan yang diproduksi oleh kelompok pengolah hasil perikanan di Kota Makassar. 
BAHAN DAN METODE

Bahan-bahan yang digunakan pada penelitian ini antara lain adalah abon, nugget, bakso dan otak-otak ikan.

Penelitian ini dilakukan dengan mengambil sampel menggunakan Teknik Accidental Sampling yaitu dengan mengambil produk bakso, abon, nugget dan otak-otak ikan yang diproduksi oleh Kelompok Buyang Sejahtera dan Kelompok Barokah. Kedua kelompok merupakan kelompok pengolah hasil perikanan yang masih pemula, berlokasi dalam wilayah yang sama yaitu Kelurahan Kampung Buyang Kecamatan Mariso Kota Makassar.

Pengujian organoleptik terhadap aroma, rasa, tekstur dan warna produk dilakukan dengan menggunakan skala hedonik. Menggunakan 5 orang panelis terbatas. Panelis memberikan respon kesukaan pada produk, yaitu: sangat suka (4), suka (3), agak suka (2), dan tidak suka (1). Respon panelis, disajikan dalam bentuk tabel dan dideskripsikan.

\section{HASIL DAN PEMBAHASAN}

\section{Abon Ikan}

Hasil uji tingkat kesukaan dan kualitas organoleptik terhadap aroma, rasa, tekstur dan warna produk abon ikan yang diproduksi kelompok Buyang Sejahtera dapat dilihat pada Tabel 1.
Tabel 1. Hasil Uji Tingkat Kesukaan dan Kualitas Organoleptik Abon Ikan Setelah Penerapan IbM

\begin{tabular}{|c|c|c|c|c|}
\hline \multirow{2}{*}{ Panelis } & \multicolumn{4}{|c|}{ Parameter organoleptik } \\
\cline { 2 - 5 } & Aroma & Rasa & Tekstur & $\begin{array}{c}\text { Warn } \\
\text { a }\end{array}$ \\
\hline 1 & 4 & 4 & 4 & 4 \\
\hline 2 & 4 & 4 & 4 & 4 \\
\hline 3 & 4 & 4 & 4 & 4 \\
\hline 4 & 4 & 4 & 4 & 4 \\
\hline 5 & 4 & 4 & 4 & 4 \\
\hline Total & 20 & 20 & 20 & 20 \\
\hline Rataan & 4 & 4 & 4 & 4 \\
\hline
\end{tabular}

Dari Tabel 1 diketahui bahwa, seluruh panelis menunjukkan rasa sangat suka terhadap aroma, rasa, tekstur dan warna abon ikan yang diproduksi oleh kelompok Buyang Sejahtera. Berbeda dengan abon yang selama ini diproduksi oleh Kelompok Buyang Sejahtera, rata-rata panelis memberi nilai suka dan agak suka. Selama ini, dalam memproduksi abon, kelompok Buyang Sejahtera menggunakan santan dan asam jawa, tetapi dalam penerapan IbM, kedua bahan tersebut diganti dengan bahan yang lain.

Abon yang diproduksi kelompok Buyang Sejahtera menggunakan tetelan daging ikan Tuna. Dalam proses pembuatannya, kelompok Buyang Sejahtera meniadakan penggunaan santan, dan mensubtitusi penggunaan asam jawa dan gula merah dengan jeruk nipis dan gula pasir. Abon ikan yang diproduksi kelompok Buyang Sejahtera dapat dilihat pada Gambar 1. 


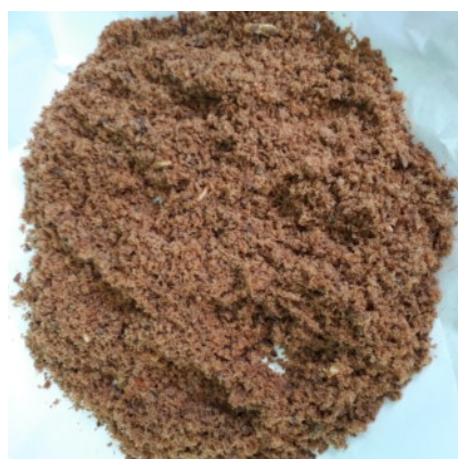

Gambar 1. Abon Ikan

Abon ikan yang diproduksi kelompok Buyang Sejahtera memiliki aroma yang khas, rasa yang enak, tekstur yang renyah dan berwarna kecokletan. Restu (2016), yang melakukan penambahan kelapa parut dalam proses pembuatan abon, menghasilkan produk dengan spesifikasi kenampakan bersih dan menarik; aroma harum menarik selera; tekstur kurang renyah, karena adanya terasa serat kelapa parut yang kurang lembut; rasa enak dan gurih.

Purnomo (1995) dalam Alik, dkk (2014) menuliskan bahwa aroma produk daging berasal dari sejumlah bahan yang ada dalam lemak dan bersifat menguap ketika dipanaskan. Bumbu yang digunakan dalam pembuatan abon dapat memberikan aroma yang khas. Bawang merah memiliki bau dan citarasa yang khas yang ditimbulkan oleh adanya senyawa yang mudah menguap dari jenis sulfur seperti propil sulfur. Kombinasi gula, garam dan bumbu-bumbu menimbulkan bau yang khas pada produk akhir. Rasa yang menentukan penerimaan konsumen yaitu tingkat kegurihan, keasinan dan rasa daging. Rasa khas yang terdapat pada abon berasal dari ketumbar yang menimbulkan rasa pedas dan mempunyai aktivitas lipolitik dan aktivitas antioksidan.
Fachruddin (2003) menambahkan bahwa rasa enak pada abon ikan disebabkan oleh adanya asam-asam amino pada protein serta lemak yang terkandung di dalam ikan.

Tekstur merupakan faktor yang berpengaruh terhadap penilaian, karena tekstur suatu makanan akan terasa saat konsumen memakannya. Abon ikan pada umumnya memiliki tekstur yang lembut, bumbu-bumbu yang menempel pada daging pada saat diolah dapat menyebabkan tekstur abon menjadi kasar (Adhadinia, 2009) dalam (Alik dkk., 2014). Lebih lanjut, dijelaskan bahwa warna merupakan salah satu parameter yang penting dalam menilai tingkat penerimaan konsumen. Warna abon dipengaruhi oleh perlakuan sebelum dan sesudah penggorengan. Timbulnya perubahan warna pada saat penggorengan diakibatkan oleh reaksi Milliard.

\section{Bakso Ikan}

Hasil uji tingkat kesukaan dan kualitas organoleptik terhadap aroma, rasa, tekstur dan warna produk bakso ikan yang diproduksi kelompok Barokah dapat dilihat pada Tabel 2.

Tabel 2. Hasil Uji Tingkat Kesukaan dan Kualitas Organoleptik Bakso Ikan

\begin{tabular}{|c|c|c|c|c|}
\hline \multirow{2}{*}{ Panelis } & \multicolumn{4}{|c|}{ Parameter organoleptik } \\
\cline { 2 - 5 } & Aroma & Rasa & Tekstur & Warna \\
\hline 1 & 3 & 3 & 3 & 3 \\
\hline 2 & 3 & 3 & 3 & 2 \\
\hline 3 & 3 & 3 & 3 & 3 \\
\hline 4 & 3 & 3 & 3 & 3 \\
\hline 5 & 3 & 3 & 2 & 3 \\
\hline Total & 15 & 15 & 14 & 14 \\
\hline Rataan & 3 & 3 & 2,8 & 2,8 \\
\hline
\end{tabular}


Dari Tabel 2 diketahui bahwa, seluruh panelis menunjukkan rasa suka dengan memberikan skor 3 terhadap aroma dan rasa. Rasa agak suka sampai suka terhadap tekstur dan warna Panelis 5 memberikan tekstur dan warna bakso ikan yang diproduksi oleh kelompok barokah. Rata-rata tingkat kesukaan panelis terhadap bakso yang diproduksi kelompok barokah selama penerapan IbM, masih di atas nilai rata-rata penilaian panelis terhadap bakso yang selama ini (sebelum penerapan IbM). Bakso yang diproduksi kelompok Barokah sebelum penerapan IbM, masih sangat kenyal atau alot dan perbandingan bumbu yang tidak sesuai sehingga menimbulkan ada rasa bumbu (merica) yang sangat terasa. Panelis ratarata memberikan nilai 2 atau agak suka terhadap parameter organoleptik bakso yang diproduksi kelompok barokah sebelum penerapan IbM.

Bakso ikan yang diproduksi kelompok Buyang Sejahtera dapat dilihat pada Gambar 2.

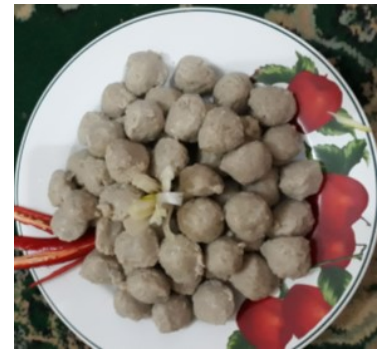

Gambar 2. Bakso Ikan

Cahyaningrum, dkk. (2015) menuliskan bahwa menurut panelis hal yang terpenting dalam menilai bakso ikan adalah rasa. Sedangkan urutan aspek mutu selanjutnya adalah tekstur, kenampakan, dan bau.
Bakso ikan yang diproduksi kelompok Barokah memiliki karakteristik aroma ikan yang kuat, rasa yang enak, tekstur kenyal dan padat dengan rasa ikan enak dan gurih, warna agak keabu-abuan.

\section{Nugget Ikan}

Hasil uji tingkat kesukaan dan kualitas organoleptik terhadap aroma, rasa, tekstur dan warna produk nugget ikan yang diproduksi Buyang Sejahtera dan Barokah dapat dilihat pada Tabel 3.

Tabel 3. Hasil Uji Tingkat Kesukaan dan Kualitas Organoleptik Nugget Ikan

\begin{tabular}{|c|c|c|c|c|c|c|c|c|}
\hline \multirow{2}{*}{$\begin{array}{l}\frac{n}{0} \\
\frac{0}{0} \\
\underline{\alpha}\end{array}$} & \multicolumn{4}{|c|}{$\begin{array}{c}\text { Parameter } \\
\text { organoleptik/ } \\
\text { Kelompok } \\
\text { Buyang } \\
\text { Sejahtera }\end{array}$} & \multicolumn{4}{|c|}{$\begin{array}{c}\text { Parameter } \\
\text { Organoleptik/ } \\
\text { Kelompok } \\
\text { Barokah }\end{array}$} \\
\hline & $\begin{array}{l}\text { Ẽ } \\
\frac{0}{\alpha} \\
\frac{1}{\alpha}\end{array}$ & 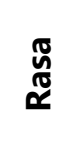 & $\frac{\text { 方 }}{\underline{y}}$ & 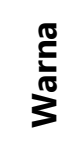 & 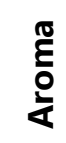 & 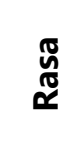 & $\begin{array}{l}\frac{5}{2} \\
\frac{n}{0} \\
\stackrel{0}{0}\end{array}$ & $\sum_{\frac{\pi}{2}}^{\frac{\pi}{3}}$ \\
\hline 1 & 4 & 4 & 4 & 4 & 3 & 2 & 3 & 3 \\
\hline 2 & 4 & 4 & 4 & 4 & 3 & 2 & 3 & 3 \\
\hline 3 & 4 & 4 & 4 & 4 & 3 & 2 & 3 & 2 \\
\hline 4 & 4 & 4 & 4 & 4 & 3 & 2 & 3 & 3 \\
\hline 5 & 4 & 4 & 4 & 4 & 3 & 2 & 3 & 3 \\
\hline $\begin{array}{l}\bar{\pi} \\
\stackrel{0}{0} \\
⺊\end{array}$ & 20 & 20 & 20 & 20 & 15 & 10 & 15 & 14 \\
\hline 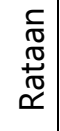 & 4 & 4 & 4 & 4 & 3 & 2 & 3 & 2,8 \\
\hline
\end{tabular}

Dari Tabel 3 diketahui bahwa, seluruh panelis menunjukkan rasa sangat suka terhadap aroma, rasa, tekstur dan warna nugget yang diproduksi kelompok Buyang Sejahtera. Panelis menunjukkan rasa suka dengan memberikan skor 3 terhadap aroma dan tekstur, rasa agak suka sampai suka terhadap warna, dan rasa agak suka dengan memberi skor 2 
pada rasa produk nugget ikan yang diproduksi kelompok Barokah. Adanya rasa agak suka terhadap rasa akibat penggunaan garam dan penguat rasa yang berlebih atau melibihi takaran pada nugget ikan kelompok barokah. Produk nugget ikan kelompok Buyang Sejahtera dan barokah dapat dilihat pada Gambar 3.

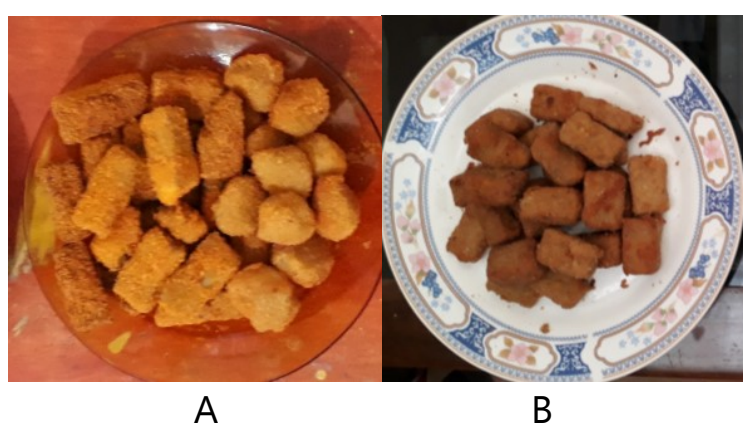

Gambar 3. A. Nugget Kelompok Barokah,

B. Nugget Kelompok Buyang Sejahtera

\section{Otak-otak Ikan}

Hasil uji tingkat kesukaan dan kualitas organoleptik terhadap aroma, rasa, tekstur dan warna produk otak-otak ikan yang diproduksi Buyang Sejahtera dan Barokah dapat dilihat pada Tabel 4.

Tabel 4. Hasil uji tingkat kesukaan dan kualitas organoleptik otak-otak ikan

\begin{tabular}{|c|c|c|c|c|c|c|c|c|}
\hline \multirow{2}{*}{$\frac{\frac{n}{0}}{\frac{0}{0}}$} & \multicolumn{4}{|c|}{$\begin{array}{c}\text { Parameter } \\
\text { organoleptik/ } \\
\text { Kelompok } \\
\text { Buyang Sejahtera }\end{array}$} & \multicolumn{4}{|c|}{$\begin{array}{c}\text { Parameter } \\
\text { Organoleptik/ } \\
\text { Kelompok } \\
\text { Barokah }\end{array}$} \\
\hline & $\frac{\text { Q }}{\mathfrak{s}}$ & 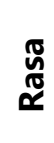 & $\begin{array}{l}\frac{5}{3} \\
\frac{y}{y} \\
\frac{v}{0}\end{array}$ & $\sum_{\frac{\pi}{2}}^{\frac{\pi}{3}}$ & 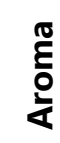 & 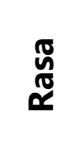 & 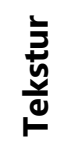 & ${ }_{\frac{\pi}{2}}^{\frac{\pi}{3}}$ \\
\hline 1 & 3 & 2 & 4 & 3 & 4 & 4 & 4 & 4 \\
\hline 2 & 2 & 2 & 4 & 2 & 4 & 4 & 4 & 4 \\
\hline 3 & 2 & 2 & 4 & 3 & 4 & 4 & 4 & 4 \\
\hline 4 & 3 & 2 & 4 & 3 & 4 & 4 & 4 & 4 \\
\hline 5 & 2 & 1 & 4 & 3 & 4 & 4 & 4 & 4 \\
\hline $\begin{array}{l}\bar{\pi} \\
\stackrel{0}{0} \\
\qquad\end{array}$ & 12 & 9 & 20 & 14 & 20 & 20 & 20 & 20 \\
\hline
\end{tabular}

\begin{tabular}{|c|c|c|c|c|c|c|c|}
\hline $\begin{array}{l}\bar{\pi} \\
\frac{\pi}{\pi} \\
\frac{\pi}{\pi}\end{array}$ & 2,4 & 1,8 & 4 & 2,8 & 4 & 4 & 4 \\
\hline
\end{tabular}

Dari Tabel 4 diketahui bahwa, seluruh panelis menunjukkan rasa sangat suka terhadap aroma, rasa, tekstur dan warna otak-otak yang diproduksi kelompok Barokah. Panelis menunjukkan rasa agak suka sampai suka dengan memberikan skor 2-3 terhadap aroma dan warna, rasa tidak suka-agak suka terhadap rasa dengan memberikan skor 1 - 2, dan rasa sangat suka dengan memberi skor 4 pada tekstur produk otak-otak ikan yang diproduksi kelompok Buyang sejahtera. Adanya tidak suka, agak suka pada aspek mutu rasa diduga karena penggunaan kunyit basah yang tidak sesui dengan takaran pada pengolahan produk otak-otak kelompok Buyang Sejahtera. Produk otak-otak ikan yang diproduksi Kelompok Buyang Sejahtera dan Barokah dapat dilihat pada Gambar 4.

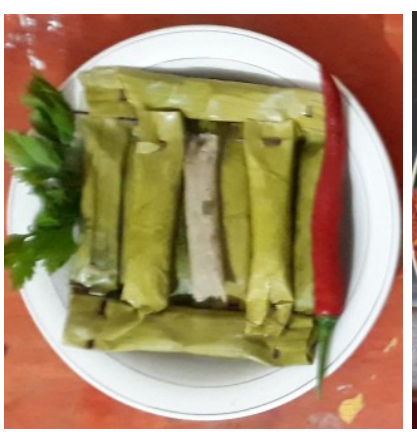

A

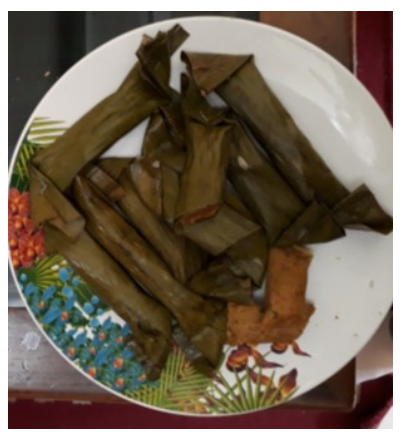

B
Gambar 4. A. Otak-otak Kelompok Barokah, B. Otak-Otak Kelompok Buyang Sejahtera

Spesifikasi bakso ikan mengacu pada SNI 7266:2014, abon ikan mengacu pada SNI 7690.1:2013, nugget ikan mengacu pada SNI 7758:2013, otak-otak mengacu pada SNI 7757:2013. 


\section{KESIMPULAN}

Berdasarkan hasil dan pembahasan, disimpulkan bahwa panelis mengatakan sangat suka terhadap produk abon dan nugget kelompok pengolah Buyang sejahtera, sangat suka terhadap produk otak-otak Kelompok Barokah, suka terhadap produk otak-otak kelompok Buyang Sejahtera serta suka terhadap produk nugget dan bakso Kelompok Barokah.

\section{DAFTAR PUSTAKA}

Alik, A. T., M. Sukmiwati dan I. Sari. 2014.
Perikanan Propinsi Sulawesi Selatan. Makassar

Fachruddin, L., 2003. Membuat Abon Ikan. Kanisius. Yogyakarta.

Kusumayanti, H., W. Astuti dan RTD. W. Broto. 2011. Inovasi Pembuatan Bakso Ikan sebagai Salah Satu Teknologi Pengawetan Ikan. Gema Teknologi 16(3):119-121

Restu. 2016. Pengolahan Abon Ikan Karandang (Channa pleurophthalmus) dengan Penambahan Kelapa Parut. Jurnal Ilmu Hewani Tropika 5(1): 21-26

Suradi, K. 2009. Tingkat Kesukaan Bakso dari Berbagai Jenis Daging Melalui Beberapa Pendekatan Statistik. Online (http://pustaka.unpad.ac.id/wpcontent/uploads/2009/11/tingkat kesukaan bakso.pdf) diakses tanggal 20 September 2017

Ancasindo. 2012. Sulsel Konsumsi Ikan 348 Ribu Ton Pertahun. Online (https://ancasindo.wordpress.com/ 2012/02/04/sulsel-konsumsi-ikan348-ribu-ton-pertahun/D Diakses Tanggal 1 Juni 2016

Cahyaningrum, D., T. W. Agustini, dan Romadhon. 2015. Pengaruh Frekuensi Pencucian Yang Berbeda Terhadap Kualitas Bakso Ikan Gabus (Ophiocephalus striatus). Jurnal Pengolahan dan Bioteknologi Hasil Perikanan 4(2):33-39

Dinas Kelautan dan Perikanan Propinsi Sulawesi Selatan. 2015. Statistik Perikanan Tangkap Sulawesi Selatan. Dinas Kelautan dan 